\title{
Investigation of the Effect of Creative Relaxation Exercises on Preschoolers'Self-concept and Motor Creativity*
}

\author{
Nezahat H. KARACA**
}

Received: 06 October 2015

\author{
Neriman ARAL ***
}

Accepted: 09 August 2016

\begin{abstract}
This research was carried out to develop creative relaxation education program appropriate for the needs and interests of children who currently attend the nursery schools and to investigate whether the creative relaxation education is effective for their self-concept and motor creativity. The research was conducted in an empirical way with a control group of pre- and post-test and retention test. Besides, "General Information Form", Perception of Child Self Concept, which was developed by Villa and Auzmendi (1992) for the children at the age of 5-6 in order to evaluate their self-concept and also Creatively Thinking Test In Action And Movement, which was developed by Torrance (1981) for children between the age of 3-8 in order to evaluate their motor creativity were used. According to the study's results, it was determined that no significant differences existed in the pre-test scores of children of experimental and control groups while there was a considerable difference in favor of the experimental group in the post-test scores of children of experimental and control groups. It was determined that the difference between post-test and retention test scores of children in experimental group is nonsignificant.
\end{abstract}

Keywords: self concept, motor creativity, relaxation, perception of child self concept, thinking creatively in action and movement test.

\section{Extended Abstract}

Purpose and Significance: This study was conducted with the aim of developing creative relaxation education program that is appropriate for the needs and interests of children who currently attend the nursery schools. The study also investigates whether the creative relaxation education is effective for their self concept and motor creativity. One of the most important critisms is that today's education institutions leave the feelings aside during education. In fact, one of the important goals of education is to upskill the individuals with the ability to realize their own feelings and to express them clearly. When a child shows his observations and experiences through different roles, he expresses his feelings through various body movements. This gives the child the opportunity to use his body according to his aim and helps him realize the characteristics of his own body to develop his abilities. In creative relaxation education program that was created to support children's motor creativity and self concept, it is

\footnotetext{
*This study was taken from a section of first author's doctoral thesis. This paper was also presented 4. Uluslararas1 Okul Öncesi Eğitimi Kongresi, 2-5 Eylül 2015.

** Corresponding Author: Yrd. Doç. Dr., Afyon Kocatepe University, Afyonkarahisar, Turkey, nhkaraca@aku.edu.tr ****Prof. Dr., Ankara University, Ankara, Turkey, aralneriman@gmail.com
}

\section{Citation Information}

Karaca, N. H., \& Aral, N. (2017). Yaratıcı rahatlama çalişmalarinin anaokuluna devam eden çocukların benlik kavramı ve motor yaratıcılığına etkisinin incelenmesi. Kuramsal Eğitimbilim Dergisi [Journal of Theoretical Educational Science], 10(1), 146-169. 
especially important that children express themselves in a different way and, accordingly, some relaxing activities were prepared.

Methods: The study's participants are children whose parents are alive and who have normal development and attending the independent nursery schools, which exist within the structure of Ministry of National Education, in 2014-2015 academic years in Afyonkarahisar. The study took place in two independent nursery schools chosen by simple random sampling method. One of the schools was determined as the experimental group, while the other is control group. The research was conducted in an empirical pattern with a control group of pre- and post-test and retention test. 24 children currently attending to nursery school were included in the experimental group; on the other hand, 22 children currently attending to nursery school were in the control group. The children in the experimental group were practiced the creative relaxation education program for ten weeks in addition to their pre-school education program. On the other hand, the children in the control group carried on with their pre-school education program only. "General Information Form", Perception of Child Self Concept which was developed by Villa and Auzmendi (1992) for the children at the age of 5-6 in order to evaluate their self concept and also Creatively Thinking Test in Action and Movement which was developed by Torrance (1981) for children between the age of 38 in order to evaluate their motor creativity were used in the research.

Data collection tools in the research were used after conducting a validity-reliability study for Creatively Thinking Test in Action and Movement and Perception of Child Self Concept assessment tool. A normality test was carried out in the analysis of data and according to the results of normal distribution test; Mann-Whitney $U$ test, Wilcoxon Signed-Rank Test, Friedman Test, One-way ANOVA test, multiple comparisons tests, paired and independent samples t-tests were used.

According to the study's results, it was found out that no significant difference existed in Perception of Child Self Concept assessment tool's pretest scores of children of experimental and control group ( $U=925.50, \mathrm{p}>.01)$, while- for the children of the experimental group- there was a considerable difference in the mean scores of pretestposttest and retention tests $\left(x^{2}=16.710, p=.000\right)$ of Perception of Child Self Concept assessment tool. Also, it was found out that the difference between Perception of Child Self Concept's pretest and posttest mean scores $(\mathrm{p}<.01)$ of children of experimental group is significant, the difference between the posttest and retention test is insignificant (p>.01), Perception of Child Self assessment tool's pretest and protest scores are not statistically different $(\mathrm{z}=-1.12, \mathrm{p}>.01)$ of children of the control group.

In the results of the analysis related to the Creatively Thinking Test in Action and Movement, it was determined that the sub-dimensions of Creatively Thinking Test in Action and Movement - fluency ( $\mathrm{U}=250.5, p=.766)$, originality $(\mathrm{U}=271.5, p=.305)$ and imagination dimensions ( $\mathrm{t}=-.073, p=.942)$ of the children in both experimental and control groups have no significant difference in the pretest mean scores $(p>.01)$; Creatively Thinking Test in Action and Movement - fluency ( $\mathrm{U}=67, p=.000)$, originality 
$(\mathrm{U}=77, p=.000)$ and imagination dimensions $(\mathrm{t}=4.597, p=.000)$ of the children in both experimental and control groups have a significant difference in the posttest mean scores ( $\mathrm{p}<.01)$; Creatively Thinking Test in Action and Movement - fluency $(\mathrm{F}=$ 119.747, $p=.000)$, originality $\left(x^{2}=43.300, p=.000\right)$ and imagination dimensions $(\mathrm{F}=122.765, p=.000)$ of the children in the experimental group have a significant difference in the pretest, posttest and retention tests' mean scores. In order to determine between which groups is the significant difference, the data were put to multiple comparisons and Bonferroni tests. As a result of these tests, it was determined that there was a significant difference between the pretest-posttest and pretest-retention test. Creatively Thinking Test in Action and Movement - fluency $(z=-1.427, p=.154)$, originality $(z=-1.793, p=.073)$ and imagination dimensions $(\mathrm{t}=-1.452, p=.161)$ of the children in the control group have an insignificant difference in the pretest and posttest mean scores $(p>.01)$.

Discussion and Conclusions: It was concluded that the change -before and during the Creative Relaxation Education Program- that was observed in the children who participated the program as the experimental group was much more significant than the one which was observed in the children of the control group, with regard to perception of child self concept and motor creativity. It was determined the positive effect of creative relaxation education program was proceeding for the development of perception of child self concept and motor creativity of the children in the experimental group. The results of the study support that the achievements of an individual during his creativity process form a basis for a positive self concept. In addition, in accordance with the results of the study, some suggestions were made to parents, teachers, and researchers. 


\title{
Yaratıcı Rahatlama Çalışmalarının Anaokuluna Devam Eden Çocukların Benlik Kavramı ve Motor Yaratıcılığına Etkisinin İncelenmesi*
}

\author{
Nezahat H. KARACA**
}

\author{
Neriman ARAL ***
}

\begin{abstract}
Makale Gönderme Tarihi: 06 Ekim 2015
Makale Kabul Tarihi: 09 Ağustos 2016

ÖZ: $\mathrm{Bu}$ araştırma, anaokuluna devam eden çocukların ilgi ve ihtiyaçlarına uygun yaratıcı rahatlama eğitim programının geliştirilmesi ve benlik kavramı ve motor yaratıcılık becerilerinde yaratıcı rahatlama eğitiminin etkili olup olmadığının incelenmesi amacıyla yapılmıştır. Araştırma ön test-son test-kalıcılık testi kontrol gruplu deneysel desende gerçekleştirilmiştir. Araştırmada "Genel Bilgi Formu”, çocukların benlik kavramlarını değerlendirmek amacıyla Villa ve Auzmendi (1992) tarafindan beş-altı yaş çocukları için geliştirilmiş olan Çocuğun Benlik Kavramını Algılaması ölçme aracı ve motor yaratıcılığının değerlendirilmesi için Torrance (1981) tarafından üç-sekiz yaş çocukları için geliştirilmiş olan Eylem ve Harekette Yaratıcı Düşünme Testi kullanılmıştır. Araştırma sonucunda, deney ve kontrol grubundaki çocukların "Çocuğun Benlik Kavramını Algılaması” ölçme aracına ve Eylem ve Harekette Yaratıcı Düşünme Testi”ne ilişkin yapılan ön test puanları arasında anlamlı farklılık olmadı̆̆ı, son test puanları arasında ise deney grubunun lehine anlamlı farklılık olduğu, ayrıca deney grubundaki çocukların son test ve kalıcılık testi puanları arasındaki farkın anlamlı olmadığı belirlenmiştir.
\end{abstract}

Anahtar kelimeler: benlik kavramı, motor yaratıcılık, rahatlama, çocuğun benlik kavramini algilamasi, eylem ve harekette yaratici düşünme testi.

\section{Giriş}

Bireyi diğer bireylerden ayıran ve farklı kılan kişilik, mizaç, karakter, benlik kavramı gibi birçok özelliği kapsayan geniş bir sistemdir. Kişilik, kalıtım ve çevrenin etkisi ile gelişmekte ve kendilerine özgü özellikleri ile her bireyin olaylar karşısındaki farklı tutum ve davranışlarının tümü olarak tanımlanmaktadır (Passer \& Smith, 2003: 420). Kişilik gelişimi, bebeklik çağında başlamakta ve yaşam boyu devam etmektedir. $\mathrm{Bu}$ süreçte kişilik ve benlik arasında güçlü bir ilişki bulunmaktadır. Kişiliğin güçlü ve bağımsız kısmını oluşturan benliğin gelişimi, insan yaşamını önemli derecede etkilemektedir. Çünkü benliğin gelişmesinde deneyim ve yaşantılar son derece önemli olup, bu deneyim ve yaşantılar, bireylerin duygusal ve sosyal yaşamlarını derinden etkilemektedir. Birey, kendi özellikleri ile ilgili olumlu ya da olumsuz birçok bilgiyi çevresindeki insanların kendileri hakkındaki düşüncelerinden, kendilerine gösterilen davranış ve tepkilerden öğrenmektedir (Gallahue, 2003; Tortamış-Özkaya, 2013). Bee ve Boyd (2009) benliği, "bireyin kişiliğinin temelinde bulunan ve birey için çok önemli olan kendisi ile ilgili düşüncelerine, algılarına, yeteneklerine ve değer yargılarına ilişkin geliştirdiği görüşleri” olarak tanımlamaktadır.

Çocuğun benlik gelişiminde ilk sosyal ortamı olan, fiziksel ve duygusal gereksinimlerini karşıllayan anne ile babadır. Anne ve babanın çocuğuna karşı tutumu, onu karşılıksız sevmesi, değer vermesi, ayrıca çocuğun bulunduğu girişimleri desteklemesi olumlu benlik kavramı gelişmesine yardımcı olacaktır (Pesu, Viljaranta, \&

\footnotetext{
* Bu çalışma Nezahat Hamiden KARACA’nın doktora tezinden üretilmiştir. Bu çalışma 4. Uluslararası Okul Öncesi Eğitimi Kongresi, 2-5 Eylül 2015’te sunulmuştur.

** Sorumlu yazar: Yrd. Doç. Dr., Afyon Kocatepe Üniversitesi, Afyonkarahisar, Türkiye, nhkaraca@aku.edu.tr

****Prof. Dr., Ankara Üniversitesi, Ankara, Türkiye, aralneriman@ gmail.com
} 
Aunola, 2016). Aynı zamanda ailenin sosyo-ekonomik durumu, eğitim durumu, anne babanın birlikte ve/veya sağ olması gibi etkenlerin benlik kavramı gelişimi üzerinde önemli etkileri bulunmaktadır (Spilt, Van, Leflot, Onghena, \& Colpin, 2014). Ailenin yanı sıra, çocuğun kendine güvenmesi ve üretken olmasındaki diğer bir destek kaynağ1 ise öğretmenlerdir. Öğretmenlerin çocukların sorunlarına eğilebilmesi ve destekleyici rol üstlenebilmesi çocukların benlik kavramının gelişimine olumlu katkı sağlamaktadır. Benliğin olumlu yönde şekillenmesi çocuğun toplum içindeki uyumunu da kolaylaştırmaktadır (Berk, 2013; İnan, 2013; Köksal-Akyol \& Sali, 2013 ). Bireyin, benlik kavramının gelişiminde anne-baba, kardeş, öğretmen gibi çevresinde bulunan kişiler tarafindan olumlu yönde desteklenmesi sonucunda olumlu benlik kavramı (Köksal Akyol \& Salı, 2013), aksi durumda ise olumsuz benli kavramı gelişmektedir (Demolin, 2000). Bireyde benlik kavramının olumlu ya da olumsuz gelişmesinde, çevresindeki bireyler ile olan ilişkilerinin etkili olduğunu destekleyen çalışmalar bulunmaktadır (Adana \& Kutlu, 2009; Brown, Mangelsdorf, Neff, Sullivan \& Frosch 2009; Can, 2015; Köksal-Akyol \& Sal1, 2013; Özkara, 2014; Schempp, 1981; Y1ldı Çiçekler \& Alakor Pirpir, 2015).

Eğitim sistemimiz sağlıklı kişilik gelişimine sahip bireyler yetiştirmenin yanında, hızla değişen ve gelişen teknolojiye ayak uydurabilen, kendi özelliklerinin farkında olan yaratıcı bireyler yetiştirmeyi hedeflemektedir. (Ömeroğlu \& Turla, 2001; Oakley, 2004). İnsan yaşamının her döneminde görülen yaratıcılı̆̆ın, yaşam kalitesini arttırmada, bireyin yaratıcı düşünme ve sorunlara yaratıcı çözümler bulabilmede önemli görevleri vardır (Çelebi-Öncü, 2014). Günlük yaşamdan bilimsel çalışmalara kadar geniş bir yelpazeyi içine alan yaratıcılık, doğuştan gelmekte ve her bireyde bulunmasına rağmen yaratıcılığın sürekliliği, gelişimi, derecesi ve ortaya çıkışı bireyden bireye farklılık göstermektedir (Gürsoy, 2001). Aslan ve Puccio (2006) yaratıcılığ1; "Yeni, özgün ve beceriye dayalı bir ürün olarak ortaya çıkmış veya henüz ürüne dönüşmemiş, kendine özgü bir problem çözme sürecini içeren, bireyin zekâ unsurlarını da özgün ve üretime dönük kullandığ1 bir bilişsel yetenek" olarak tanımlamışlardır. Yaratıcılığı ortaya çıkarmak ve geliştirebilmek için her şeyden önce bireyin kendine güven duyması, bağımsız düşünebilmesi, kimi zaman alışılmış kalıpların ve kuralların dışına çıkabilmesi ve yeteneklerini sonuna kadar kullanabileceği ortam ve özgürlüğe sahip olması gerekmektedir (Aral, 1999). Doğuştan gelen, ortam ve koşullara göre gelişebilen, hatta ilk yıllarda desteklenmesi gereken yaratıcılık yeteneğinin gelişiminde aile, okul, öğretmen ve çocuğun kendini demokratik bir ortamda değerli görmesinin yanında rahat ve güvende olması etkili etmenler arasındadır. Can Yaşar ve Aral (2010-2011) yaptıkları çalışmalarda, okul öncesi dönem çocuklarının yaratıcı düşünme becerilerinin ortaya çıkma sürecinde okul öncesi eğitimi almalarının, sosyo-ekonomik düzeylerinin ve anne baba öğrenim durumlarının etkili olduğunu belirtmişlerdir. Ayrıca Guilford (1971), benlik algısı ve yaratıcılık arasında ilişkinin varlığına dikkat çekmiş, olumlu bir benlik algısına sahip olmanın bireydeki yaratıcı potansiyelin ortaya çıkmasını desteklediğini vurgulamıştır. Bazı bilim insanları olumlu benlik kavramının yaratıcı potansiyelin ortaya çıkarmasında etkili olduğuna dikkat çekerken, bazı bilim insanları 
da yaratıcı potansiyelin olumlu benlik algısına katkı sağladığına dikkat çekmişlerdir (Akt: Justo, 2008).

Yaratıcılığın bir boyutu olan motor yaratıcılık ile benlik kavramı arasında da sıkı bir ilişki bulunmaktadır. Motor yaratıcılık, yeni ve taze yapıları algılama kombinasyonu olarak tanımlanmakta ve bunlar ya yapılandırılmamış bir problemin çözümü ya bir fikrin açıklanması ya da bir duygunun vücut yoluyla ifade edilmesi şeklinde belirtilmektedir (Bournelli \& Mountakis, 2008). Hareket, çocukların kendileri ve çevrelerini tanıması için en temel ve vazgeçilmez gereksinimler arasında yer almaktadır. Çocuklar, aynı zamanda etraflarındaki diğer şeyleri de fark etmeye başladıkları zaman bedenlerinin varlığını keşfetmekte, bu durum çocukta hareket farkındalığına temel oluşturmakta ve motor yaratıcılığın gelişmesine katkı sağlamaktadır (Wang, 2003). Yaratıcılık ve motor yaratıcılığın ortaya çıkarılmasında, aynı zamanda da var olan yaratıcılığın desteklenmesinde harekete dayalı rahatlama çalışmalarının etkili olabileceği söylenebilir. Günlük yaşamda karşılaşılan pek çok problem durumunun çözümünde, gerginlik ve stresin azaltılmasında önemli bir yer tutan rahatlama çalışmaları sayesinde çocuklar çevredekilerle daha açık ve olumlu bir iletişim kurma firsatı elde edebilmektedir. Ayrıca bu tür çalışmalar, çocukların dikkatlerini bedenlerine yoğunlaştırmalarını, bedenlerinin farkına vararak rahatlamalarını ve yaratıcılıklarını geliştirmelerini olanak sağlamaktadır (Justo, 2008).

Her bireyde var olan geliştirilmeyi ve desteklenmeyi bekleyen yaratıcılık, farklı eğitim yöntemleri kullanılarak ortaya çıkarılabilir (Makero, 2012). Yapılan çalışmalarda, okul öncesi eğitimin çocukların yaratıcılıklarını geliştirebilme ve yaratıcı hareketlerini açıkça gösterebilmelerini sağlayabilmede önemli dönemler arasında yer aldığı ortaya konmuştur. Bu dönemdeki çocukların hareket etmeye karşı ilgilerinin çok olması nedeniyle hareket etkinlikleri ile çocukların deneyimleri zenginleştirildiğinde, çocuklar bedenlerini daha rahat hissedebildikleri ve hareket aracılığıyla kendilerini daha rahat ifade edebildikleri belirtilmiştir (Cheung, 2010; Erbay, 2009;Felker \& Treffinger, 1971; Justo, 2008; Torrance, 1981). Bu doğrultuda hazırlanan eğitim programlarının çocukların kendine olan güvenlerini arttırmada, olumlu benlik geliştirmede etkili olabileceği, bunlarla birlikte yaratıcılığ kazanımların yaşam boyu devam edebileceği düşünülmektedir (Marx \& Winne, 1975). $\mathrm{Bu}$ bağlamda çocukların bu gereksinimlerini karşılamaya dönük farklı rahatlama programlarına ve etkinliklere gereksinim duyulduğu söylenebilir. Türkiye alan yazınında, motor yaratıcılık ile benlik kavramını birlikte ele alan ve yaratıcı rahatlama çalışmalarının etkisini inceleyen çalışmaların olmadığı, uygulamaya dönük çalışmalara gereksinim duyulduğu görülmektedir. Bu noktadan hareketle araştırmada, anaokuluna devam eden çocukların ilgi ve gereksinimlerine uygun yaratıcı rahatlama eğitim programının geliştirilmesi, benlik kavramı ve motor yaratıcılık becerilerinde yaratıcı rahatlama eğitiminin etkili olup olmadığının incelenmesi amaçlanmıştır. 


\section{Yöntem}

Araştırma, anaokuluna devam eden çocukların ilgi ve gereksinimlerine uygun yaratıcı rahatlama eğitim programının geliştirilmesi, benlik kavramı ve motor yaratıcılık becerilerinde yaratıcı rahatlama eğitiminin etkili olup olmadığını incelemek amacıyla, öntest-sontest-kalıcılık testi deney ve kontrol gruplu deneysel desen kullanılarak gerçekleştirilmiştir. Araştırmada bağımlı değişken anaokulu çocuklarının "benlik kavramı ve motor yaratıcılık", çocukların benlik kavramı ve motor yaratıcılıkları üzerine etkisi incelenen bağımsız değişken ise "Yaratıcı Rahatlama Eğitim Programi"dir.

\section{Araştırmanın Çalışma Grubu}

Araştırmanın çalışma evrenini 2014-2015 eğitim öğretim yılında Afyonkarahisar il merkezindeki Milli Eğitim Müdürlüğü'ne bağlı bağımsız anaokullarına devam eden, normal gelişim gösteren 61-72 aylık çocuklar oluşturmaktadır. Araştırmanın çalışma grubuna, çalışma evreni içerisinden Afyonkarahisar il merkezindeki Milli Eğitim Müdürlüğ̈̈'ne bağlı bağımsız anaokullarına devam eden, daha önce benlik kavramı ve motor yaratıcılık destekleme programı uygulanmamış, deney (n: 24) ve kontrol (n: 22) grubu olmak üzere toplam 46 çocuk dahil edilmiştir. Deney grubuna uygulanacak olan Yaratıcı Rahatlama Eğitimi Programından kontrol grubundaki çocukların dolaylı olarak etkilenebilecekleri düşünüldüğünden, deney ve kontrol grubundaki çocukların farklı okullardan olmasına karar verilmiş ve Afyonkarahisar il merkezindeki okul yöneticileri ile görüşülerek bağımsız anaokulları arasından benzer sosyo-kültürel özelliklere sahip olduğu varsayılan iki okul seçilmiştir. Her okuldan sabah grubu araştırmanın çalışma grubunu oluşturmuştur.

Deney grubundaki çocukların; \%50'sinin kız, \%50'sinin erkek, \%50'sinin 61-66 aylar arasında, \%54.2'sinin ilk çocuk, \%37.5'inin bir kardeşe sahip olduğu ve \%75'inin daha önce herhangi bir okul öncesi eğitim almadıkları belirlenmiştir. Deney grubundaki çocukların annelerinin \%45.8'inin, babalarının ise \%62.5'inin 30-39 yaş arasında, annelerinin \%54.2'sinin ilkokul mezunu, babalarının \%37.5'inin lise mezunu, annelerinin \%91.7'sinin ev hanımı, babalarının \%41.7'sinin işçi ve serbest meslek sahibi olduğu ve ailelerin \%50'sinin ekonomik gelirinin 1000 TL ve altında olduğu saptanmıştır.

Kontrol grubundaki çocukların; \%36.4'ünün kız \%63.6'sının erkek, \%72.7'sinin 61-66 aylar arasında, \%40.9'unun ilk çocuk, \%54.5'inin bir kardeşe sahip olduğu ve \%95.5'inin daha önce herhangi bir okul öncesi eğitim almadıkları belirlenmiştir. Kontrol grubundaki çocukların annelerinin \%54.5'inin 29 yaş ve altında, babalarının \%72.7'inin 30-39 yaş arasında, annelerinin \%63.6'sının ilkokul mezunu, babalarının \%36.4'ünün ortaokul mezunu, annelerinin \%95.5'inin ev hanımı, babalarının \%59.1'inin serbest meslek sahibi olduğu ve ailelerin \%52.6'sının ekonomik gelirinin 1000 TL ve altında olduğu saptanmıştır. 


\section{Veri Toplama Araçları}

Araştırmada veri toplama aracı olarak, çocuklar ve aileleri hakkındaki bazı bilgileri toplamak amacıyla "Kişisel Bilgi Formu", çocukların benlik kavramlarını değerlendirmek amacıyla Villa ve Auzmendi (1992) tarafından beş-altı yaş çocukları için geliştirilmiş olan Çocuğun Benlik Kavramını Algılaması (Perception of Child SelfConcept-PCSC) Ölçme Aracı ve motor yaratıcılığının değerlendirilmesi için Torrance (1981) tarafından üç-sekiz yaş çocukları için geliştirilmiş olan Eylem ve Harekette Yaratıcı Düşünme Testi (Thinking Creatively in Action and Movement Test- TCAM) kullanılmıştır.

Kişisel bilgi formu. Çocuklar ve aileleri hakkındaki kişisel bilgileri toplamak amacıyla araştırmacılar tarafından geliştirilen formda; çocuğun doğum tarihi, cinsiyet, kardeş sayıs1, okul öncesi eğitim kurumuna devam etme süresi, anne babanın yaş1, eğitim durumu, meslekleri ve ailenin sosyo-ekonomik durumu gibi bilgilerin ortaya konulmasına yönelik sorular yer almaktadır.

Çocuğun benlik kavramını algılaması (Perception of child self-conceptPCSC). Benlik Kavramını Algılama ölçme aracı Villa ve Auzmendi (1992) tarafından beş- altı yaş çocuklarının benlik kavramının değerlendirilmesi amacı ile geliştirilmiştir. $\mathrm{Bu}$ ölçme aracı, olumlu ya da olumsuz benlik kavramına sahip olan çocukları basitçe ve ekonomik olarak tanımlamada kullanılmaktadır. Bireysel ya da küçük grup olarak beşaltı yaş çocuklarına uygulanabilmektedir. Ölçme aracı otuz dört maddeden ve her maddeye ait olan otuz dört resimden oluşmakta ve uygulama her çocuk için 15-20 dakika sürmektedir.

Çocuğun Benlik Kavramını Algılama ölçme aracına ait geçerlik ve güvenirlik analizleri; anaokullarına devam eden, normal gelişim gösteren 170 çocuk ile yapılmıştır. Ölçme aracının geçerliliği kapsam geçerliliği yapılarak sınanmış ve uzman görüşleri doğrultusunda kapsam geçerliliği sağlanmıştır. Uzmanların görüş ve önerileriyle şekillenen Çocuğun Benlik Kavramını Algılaması ölçme aracının, Afyonkarahisar İl Milli Eğitim Müdürlüğü'ne bağlı bir anaokulunda ön uygulaması (n=40) gerçekleştirilmiş ve güvenirlik katsayısının ölçme aracının tümü için (Alpha=0.564) orta derecede ayırt ettiği sonucuna ulaşılmıştır. Değerlendirmecilerin puanları arasındaki güvenirliği incelemek amacıyla "Bağımsız değerlendirmeciler arası uyum" $(n=20)$ incelenmiş ve değerlendirmecilerin puanları arasındaki korelasyonun yüksek olduğu, puanlar arasında anlaml, pozitif ve yüksek düzeyde bir ilişki olduğu ( $r=.996$, $r=.996, r=.997)$ saptanmıştır. Çocuğun Benlik Kavramını Algılaması değerlendirme ölçütlerine ilişkin $(n=170)$ madde toplam korelasyonu ve Cronbach alfa analizi sonuçlarına göre, güvenirlik katsayısı testin tümü için .69 ve madde toplam korelasyonlarının çoğunluğunun yeterli düzeyde olduğu bulunmuştur. Çocuğun Benlik Kavramını Algılaması ölçme aracının puanlarına göre oluşturulan üst \%27 ve alt $\% 27^{\prime}$ lik grupların ortalama puanları arasındaki farkın $(t=-19, p<.01)$ anlamlı çıkması, Çocuğun Benlik Kavramını Algılaması ölçme aracının maddelerinin benlik kavramının değerlendirilmesinde ayırt edici olduğu sonucunu ortaya çıkarmıştır. Çocuğun Benlik Kavramını Algılaması ölçme aracının test-tekrar test güvenirlik katsayıları $(n=40)$ iki 
test sonuçları arasındaki ilişkinin pozitif, yüksek düzeyde ve anlamlı olduğu, buna göre, Çocuğun Benlik Kavramını Algılaması ölçme aracının zamana bağlı olarak kararlı bir yap1 gösterdiği söylenebilir (Karaca, 2015).

Eylem ve harekette yaratıcı düşünme testi (thinking creatively in action and movement test- TCAM). Torrance (1981) tarafından geliştirilmiş olan Eylem ve Harekette Yaratıcı Düşünme Testi üç-sekiz yaş çocuklarının motor yaratıcılıklarının değerlendirilmesine olanak sağlayan bir ölçme aracıdır. Bu test, okul öncesi dönem çocuklarının yaratıcı düşünme yeteneklerini kinestetik modelle ifade etmelerini tanımlamada kullanılmaktadır. Test bireysel olarak uygulanabilmektedir. Test dört etkinlikten oluşmakta ve her bir etkinlik 15 dakika sürmektedir. Testin yapıldığı ortam, çocuğun rahat hareket edebilmesini sağlayacak kadar genişliğe sahip olmalıdır. Test uygulanırken dikkati dağıtabilecek unsurların ortamdan uzaklaştırılarak dikkat dağınıklığı minimum seviyede tutulmalıdır. Çocuklar sonsuz sayıda davranış yaratabildikleri için onların yaratıcı düşünme becerilerine örnek vermek güç olmaktadır. $\mathrm{Bu}$ nedenle Eylem ve Harekette Yaratıcı Düşünme Testi, küçük çocukların yaratıcı düşünme yeteneklerini kullanacakları yolları içeren dört etkinlikten (Etkinlik 1: Kaç farklı şekilde? Etkinlik 2: Şu şekilde hareket edebilir misiniz? Etkinlik 3: Diğer yollar nedir? Etkinlik 4: Bu ne olabilir?) oluşmaktadır. Testin değerlendirilmesi, akıcılık, özgünlük, hayal gücü puanlarının toplamları ve toplam puanların karşılığı olan standart puanların hesaplanması ile elde edilmektedir. İkinci etkinlik uygulama anında puanlanırken, diğer üç etkinlik testin uygulanmasından hemen sonra değerlendirilmektedir. Testin geçerlik ve güvenirlik çalışmasında, teste ait dört etkinliğin analiz işlemleri farklılık göstermektedir. Etkinliklerde standart bir yanıtlama söz konusu olmadığ 1 ve açık uçlu olduğu için geçerlik ve güvenirlik analizleri uzman görüşleri-kapsam geçerliliği ile sağlanabilmektedir (Karaca, 2015).

Eylem ve Harekette Yaratıcı Düşünme Testi'ne ait geçerlik ve güvenirlik analizleri; anaokullarına devam eden, normal gelişim gösteren 170 çocuk ile yapılmıştır. Ölçme aracının geçerliliği kapsam geçerliliği yapılarak sınanmış ve uzman görüşleri doğrultusunda kapsam geçerliliği sağlanmıştır. Uzmanların görüş ve önerileriyle şekillenen Eylem ve Harekette Yaratıcı Düşünme Testi'nin, Afyonkarahisar İl Milli Eğitim Müdürlüğü'ne bağlı bir anaokulunda ön uygulaması $(n=40)$ gerçekleştirilmiş ve güvenirlik katsayısının ölçme aracının tümü için $(\alpha=0.778)$ yeterli düzeyde olduğu belirlenmiştir. Değerlendirmecilerin puanları arasındaki güvenirliği incelemek amacıyla "Bağımsız değerlendirmeciler arası uyum" $(n=20)$ incelenmiş ve değerlendirmecilerin puanları arasındaki korelasyonun yüksek olduğu, puanlar arasında anlaml, pozitif ve yüksek düzeyde bir ilişki olduğu (akıc1lı ve özgünlük boyutlarında $r=1.000$, hayal gücü boyutunda $r=.949, r=.952, r=.965 ; p<.01)$ saptanmıştır. Eylem ve Harekette Yaratıc1 Düşünme Testi değerlendirme ölçütlerine ilişkin $(n=170)$ madde toplam korelasyonu ve Cronbach alfa analizi sonuçlarına göre, güvenirlik katsayısı testin tümü için .74 ve madde toplam korelasyonlarının çoğunluğunun yeterli düzeyde olduğu bulunmuştur. Eylem ve Harekette Yaratıcı Düşünme Testi'nin puanlarına göre oluşturulan üst \%27 ve alt \%27'lik grupların ortalama puanları arasındaki farkın $(t=-25.1, p<.01)$ anlamlı 
çıkması, Eylem ve Harekette Yaratıcı Düşünme Testi'nin motor yaratıcılıklarını ayırt ettiği sonucunu ortaya çıkarmıştır. Eylem ve Harekette Yaratıcı Düşünme Testi'nin testtekrar test güvenirlik katsayıları $(n=40)$ iki test sonuçları arasındaki ilişkinin pozitif, yüksek düzeyde ve anlamlı olduğu, buna göre, Eylem ve Harekette Yaratıcı Düşünme Testi'nin zamana bağlı olarak kararlı bir yapı gösterdiği söylenebilir.

Yaratıcı rahatlama eğitim programı. Okul öncesi eğitime devam eden çocukların benlik kavramı ve yaratıcıklarını desteklemeyi esas alan bir programdır. Araştırmada deney grubundaki çocuklara "Yaratıcı Rahatlama Eğitimi Programı" okul öncesi eğitim programı dikkate alınarak hazırlanmıştır. Program hazırlanmadan once benlik kavramı, motor yaratıcılık, yaratıcılık ve rahatlama çalışmaları ile ilgili yapılan yurt içi ve yurt dışındaki programlar incelenmiştir. Incelenen program ve literature sonrasında Okul Öncesi Eğitim Programında (2013) yer alan kazanım ve göstergeler doğrultusunda program hazırlanmıştır. Yaratıcı rahatlama eğitim programının hazırlık aşaması tamamlandıktan sonra program, iki okul öncesi öğretmeni ile okul öncesi eğitim alanında uzman yedi öğretim üyesi olmak üzere toplam dokuz uzmanın görüşüne sunulmuştur. Uzmanlardan, hazırlanan eğitim programını; belirlenen kazanım ve göstergelerin programın amacına uygunluğu, öğrenme süreçlerinin yeterliliği, uygulanabilirliği, kullanılan materyallerin uygunluğu ve yeterliliği, motor yaratıcılık ve benlik kavramlarını desteklemedeki yeterliliği ve uygunluğu ve verilen yönergelerin açıklığ1 gibi kriterleri göz önünde bulundurarak "uygun”, "kısmen uygun”, "uygun değil” şeklinde değerlendirmeleri ve düşüncelerini "açıklama” bölümünde belirtmeleri istenmiştir. Uzmanlar ayrıca kendilerine verilen "Yaratıcı Rahatlama Eğitim Programı" üzerinde görüşlerini daha ayrıntılı olarak belirtmişlerdir. Uzmanların eğitim programı üzerinde yaptıkları eleştiriler ve öneriler dikkate alınarak gerekli düzeltmeler yapılmış ve yaratıcı rahatlama eğitim programına son şekli verilmiştir.

Yaratıcı Rahatlama Eğitimi Programı özellikle çocuklarda olumlu benlik kavramı ve motor yaratıcılılarını geliştirmeyi amaçlayan, çocuk merkezli 20 etkinlikten oluşmaktadır. Yaratıcı Rahatlama Eğitim Programı ile çocuklar öncelikle fiziksel ve zihinsel rahatlamaları, ardından uygulanan etkinlikler ile de çocuğun bedenini tanırken farklı kullanım alanlarına firsat vermek amaçlanmıştır. Buradan hareketle öncelikle rahatlama çalışmaları oluşturulmuş, rahatlama çalışmalarındaki nesne ve masallar dikkate alınarak kazanım ve göstergeler doğrultusunda etkinlikler hazırlanmıştır. Rahatlama çalışmaları sırasında çocuklara kendilerini rahat hissedebilecek şekilde yere uzanmaları ve gözlerini kapatmaları istenmektedir. Rahatlama çalışması her bir etkinlikten önce yapılacak şekilde planlanmıştır. Rahatlama çalışmasının başlangıcında çocukların burunlarından nefes alarak ağızlarından vermeleri, kendilerini balon gibi hissetmeleri, şiştikçe gökyüzüne çıktıkları ve gökyüzünden görmek istedikleri her şeyi hayal etmeleri istenmektedir. Rahatlama çalışmasının son kısmında ise dönüşümlü olarak çocuklardan nesne ya da okunan masallar (nesne, top, kağıt, bardak ya da Kırmızı Başlıklı Kız, Çirkin Ördek Yavrusu gibi) ile ilgili düşünmeleri ve hayal kurmaları istenmektedir. Rahatlama çalışması sırasında okunan masallar çocuklarda yaratıcılığı destekleyebilmek için bilinen olaylardan yola çıkılarak yeni ürünler, 
hareketler, düşünceler oluşturmak amacıyla klasik masallardan seçilmiştir. Rahatlama çalışmasının sonunda verilen uyaranlar doğrultusunda çocuklarda motor yaratıcılık ve benlik kavramını geliştirici etkinlikler hazırlanmıştır. Programda yer alan drama, oyun, hareket, sanat ve müzik gibi etkinliler yoluyla çocukların kendini ve çevresini tanıma, problem çözme, yaratma, değerlendirme, soru sorma becerilerinin desteklendiğ söylenebilir. Aynı zamanda Yaratıcı Rahatlama Eğitim Programı'nda uygulanan etkinliklerin, çocuğun bağımsız düşünme yetisinin gelişmesine, yaratıcılık ve estetik gelişiminin sağlanmasına, yeni olumlu davranışlar geliştirmesine, kendine olan güvenini kazanmasına, fiziksel ve sosyal problemleri çözebilme konusunda yaparak yaşayarak deneyim kazanmasına katkı sağladığı söylenebilir.

Eğitim programında yer alan etkinlikler araştırmacı tarafindan uygulanmıştır. Uygulama sırasında sınıf mevcudu üçe (sekizer kişi) ayrılmıştır ve eğitim prıgramı farklı bir salonda uygulanmıştır. Belirlenen salonda çocukların dikkatininin dağılmaması için gerekli düzenlemeler yapılmıştır. Etkinlikler yaklaşık 60-90 dakika olacak şekilde planlanmıştır. Eğitim programının başında çocuklara rahatlama çalışması, daha sonra rahatlama çalışması ile bütünleştirilmiş etkinlikler uygulanmıştır. Araştırmacı tarafından ön testler uygulandıktan sonra, deney grubuna "Yaratıcı Rahatlama Eğitim Programı" Sal1-Perşembe günleri olma küzere on hafta boyunca uygulanmıştır. Kontrol grubunda ise, mevcut eğitim programının uygulanmasına devam edilerek, program sınıf öğretmeni tarafından doğal akışında uygulanmıştır. Eğitim programının uygulaması tamamlandiktan sonra deney ve kontrol gruplarına son test, deney grubuna üç hafta sonra kalıcılık testi uygulanmıştır.

\section{Verilerin Analizi}

Araştırmada, çocuklara ait demografik özelliklerin değerlendirilmesinde frekans ve yüzde gibi betimsel istatistikler kullanılmıştır. Verilerin analiz yöntemi, betimsel istatistik ve normallik testi sonuçlarına göre belirlenmiştir. Deney ve kontrol grubundaki çocukların Benlik Kavramını Algılaması ölçme aracına ve Eylem ve Harekette Yaratıcı Düşünme Testi'ne ilişkin ön test-son test- kalıcılık testi puan ortalamalarına ait sonuçlar normallik testi sonucuna göre, değerlerin normal dağılmaması nedeniyle gruplar arası farklılık incelenirken ikili gruplarda Mann Whitney $U$ Testi, gruplar içi karşılaştırmalarda Wilcoxen İşaretli Sıralar Testi, çoklu karşılaştırmalarda ise Friedman Testi kullanılmıştır. Değerlerin normal dağılım gösterdiği durumlarda ise, ikili karşılaştırmalarda Bağımlı ve Bağımsız Gruplar $t$ Testi, çoklu karşılaştırmalarda ise Anova Testi kullanılmıştır.

\section{Bulgular}

Anaokuluna devam eden çocukların ilgi ve gereksinimlerine uygun yaratıcı rahatlama eğitim programının geliştirilmesi, benlik kavramı ve motor yaratıcılık becerilerinde yaratıcı rahatlama eğitiminin etkisini incelemek amacıyla yapılan araştırma bulguları aşağıda sunulmuştur 
Tablo 1

Deney ve Kontrol Grubundaki Çocukların Çocuğun Benlik Kavramını Algılaması Ölçme Araci ile Eylem ve Harekette Yaratıcı Düşünme Testi'ne İlişkin Ön Test Puanlarına Ait Mann-Whitney U Testi ve Bağımsız Gruplarda t Testi Sonuçları

\begin{tabular}{|c|c|c|c|c|c|c|c|c|c|}
\hline \multirow[b]{2}{*}{ Ölçüm } & \multirow[b]{2}{*}{ Grup } & \multicolumn{5}{|c|}{ Çocuğun Benlik Kavramını Algılaması Ölçme Aracı } & \multicolumn{3}{|c|}{$M W U$} \\
\hline & & $n$ & $\bar{X}$ & Min. & $\operatorname{Max}$ & s.s. & Sira Ort. & $U$ & $p$ \\
\hline \multirow{2}{*}{ Ön Test } & Kontrol & 22 & 114.8 & 95 & 124 & 8.4 & 24.09 & \multirow{2}{*}{925.50} & \multirow{2}{*}{.774} \\
\hline & Deney & 24 & 115.4 & 99 & 129 & 7.2 & 22.96 & & \\
\hline $\begin{array}{l}\text { Boyut/ } \\
\text { Test }\end{array}$ & & \multicolumn{5}{|c|}{ Eylem ve Harekette Yaratıcı Düşünme Testi } & & & \\
\hline Akıc1lık & Deney & 24 & 70.3 & 62 & 83 & 5.7 & 22.9 & \multirow{2}{*}{250.5} & \multirow{2}{*}{.766} \\
\hline Ön Test & Kontrol & 22 & 72.3 & 62 & 95 & 8.6 & 24.1 & & \\
\hline Özgünlük & Deney & 24 & 63.7 & 0 & 87 & 29.6 & 21.6 & \multirow{2}{*}{217.5} & \multirow{2}{*}{.305} \\
\hline \multirow[t]{3}{*}{ Ön Test } & Kontrol & 22 & 70.8 & 0 & 91 & 23.7 & 25.6 & & \\
\hline & & \multirow{2}{*}{\multicolumn{5}{|c|}{ Eylem ve Harekette Yaratıcı Düşünme Testi }} & \multicolumn{3}{|c|}{ Bağımsız Gruplarda t Testi } \\
\hline & & & & & & & s.d. & $t$ & $p$ \\
\hline \multirow{2}{*}{$\begin{array}{l}\text { Hayal Gücü } \\
\text { Ön Test }\end{array}$} & Deney & 24 & 83.5 & 64.0 & 115.0 & 15.1 & \multirow{2}{*}{44} & \multirow{2}{*}{-0.073} & \multirow{2}{*}{.942} \\
\hline & Kontrol & 22 & 83.9 & 60.0 & 115.0 & 14.6 & & & \\
\hline
\end{tabular}

Tablo 1 incelendiğinde, yapılan Mann Whitney $U$ testi sonucuna göre; deney ve kontrol grubundaki çocukların Çocuğun Benlik Kavramını Algılaması Ölçme Aracı'na ilişkin ön test puan ortalamaları arasında anlamlı bir farklılık olmadığ 1 ( $U=925,50$, $p>.01$ ), Eylem ve Harekette Yaratıcı Düşünme Testi'ne yapılan Mann Whitney $U$ ve Bağımsız Gruplarda $t$ Testi sonuçlarına göre; deney ve kontrol grubundaki çocukların Eylem ve Harekette Yaratıcı Düşünme Testi alt boyutlarından akıcılık ( $U=250.5$, $p>.01)$, özgünlük $(U=271.5, p>.01)$ ve hayal gücü $(t=-.073, p>.01)$ boyutlar1, ön test puan ortalamaları arasında anlamlı bir farklılığın olmadığı belirlenmiştir. 
Tablo 2

Deney ve Kontrol Grubundaki Çocukların Çocuğun Benlik Kavramını Algılaması Ölçme Aracı ile Eylem ve Harekette Yaratıcı Düşünme Testi'ne İlişkin Son Test Puanlarına Ait Mann-Whitney U testi ve Bağımsız Gruplarda t Testi Sonuçları

\begin{tabular}{|c|c|c|c|c|c|c|c|c|c|}
\hline \multirow[b]{2}{*}{ Ölçüm } & \multicolumn{6}{|c|}{ Çocuğun Benlik Kavramını Algılaması Ölçme Aracı } & \multicolumn{3}{|c|}{ MWU } \\
\hline & Grup & $\mathrm{n}$ & $\bar{X}$ & Min. & Max. & s.s. & Sira Ort. & $\mathrm{U}$ & $\mathrm{p}$ \\
\hline \multirow{2}{*}{ Son Test } & Kontrol & 22 & 116.3 & 101 & 124 & 6.4 & 17.1 & \multirow{2}{*}{122.5} & \multirow{2}{*}{$.002 *$} \\
\hline & Deney & 24 & 122.0 & 104 & 131 & 6.1 & 29.4 & & \\
\hline $\begin{array}{l}\text { Boyut/ } \\
\text { Test }\end{array}$ & \multicolumn{7}{|c|}{ Eylem ve Harekette Yaratıcı Düşünme Testi } & & \\
\hline Akıcılık & Deney & 24 & 93.0 & 74.0 & 115.0 & 13.1 & 31.7 & \multirow{2}{*}{67} & \multirow{2}{*}{$.001 *$} \\
\hline Son Test & Kontrol & 22 & 75.3 & 63.0 & 105.0 & 9.7 & 14.5 & & \\
\hline Özgünlük & Deney & 24 & 103.9 & 79.0 & 132.0 & 16.2 & 31.3 & & \\
\hline \multirow[t]{3}{*}{ Son Test } & Kontrol & 22 & 76.4 & 0.0 & 115.0 & 27.4 & 15.0 & 77 & $.001^{*}$ \\
\hline & & \multirow{2}{*}{\multicolumn{5}{|c|}{ Eylem ve Harekette Yaratıcı Düşünme Testi }} & \multicolumn{3}{|c|}{ Băğmsız Gruplarda t Testi } \\
\hline & & & & & & & s.d. & $t$ & $P$ \\
\hline Hayal Gücü & Deney & 24 & 109.5 & 89.0 & 122.0 & 10.0 & \multirow{2}{*}{44} & \multirow{2}{*}{4.597} & \multirow{2}{*}{$.000 *$} \\
\hline Son Test & Kontrol & 22 & 90.3 & 53.0 & 118.0 & 17.6 & & & \\
\hline
\end{tabular}

Tablo 2 incelendiğinde, yapılan Mann Whitney $U$ testi sonucuna göre; deney ve kontrol grubundaki çocukların Çocuğun Benlik Kavramını Algılaması Ölçme Aracı'na ilişkin son test puan ortalamaları arasındaki farklılığın anlamlı olduğu $(U=122.5, p<.01)$ saptanmıştır. Eylem ve Harekette Yaratıcı Düşünme Testi'ne yapılan Mann Whitney $U$ ve Bağımsız Gruplarda $t$ Testi sonuçlarına göre; deney grubundaki çocukların akıcılık boyutu son test ortalama puanı 93, özgünlük boyutu son test ortalama puan1 103.9 iken kontrol grubunun akıcılık boyutu son test ortalama puanının 75.3, özgünlük boyutu son test ortalama puanının 76.4 olduğu belirlenmiştir. Gruplar arasında son test açısından anlamlı farklılık olup olmadığını belirlemek için yapılan Mann Whitney $U$ testine sonucuna göre; deney ve kontrol grubundaki çocukların Eylem ve Harekette Yaratıcı Düşünme Testi akıcılık $(U=67, p<.01)$ ve özgünlük $(U=77, p<.01)$ boyutları son test puan ortalamaları arasındaki farklılığın anlamlı olduğu belirlenmiştir.

Deney grubundaki çocukların Eylem ve Harekette Yaratıcı Düşünme testi hayal gücü boyutu son test ortalama puanı 109.5 iken kontrol grubunun hayal gücü boyutu son test ortalama puanının 90.3 olduğu belirlenmiştir. Gruplar arasında son test açısından anlamlı farklılık olup olmadığını belirlemek için yapılan Bağımsız Gruplarda $t$ Testi sonucuna göre; deney ve kontrol grubundaki çocukların Eylem ve Harekette Yaratıcı Düşünme Testi hayal gücü boyutu son test puan ortalaması arasındaki farklılığın anlamlı olduğu $(t=4.597, p<.01)$ saptanmıştır. 
Tablo 3

Kontrol Grubundaki Çocukların Çocuğun Benlik Kavramını Algılamasi Ölçme Aracı ile Eylem ve Harekette Yaratıcı Düşünme Testi'ne İlişkin Ön Test - Son Test Puan Ortalamalarına Ait Wilcoxon Isşaretli Sıralar Testi ve Bağımlı Gruplar $t$ Testi Sonuçları

\begin{tabular}{llccccccc}
\hline & \multicolumn{4}{c}{ Çocuğun Benlik Kavramını Alglaması Ölçme Aracı } & \multicolumn{2}{c}{ wilcoxon } \\
Grup & Test & $n$ & $\bar{X}$ & s.s. & Min. & Max. & $z$ & $p$ \\
\hline $\begin{array}{l}\text { Kontrol } \\
\text { Grubu }\end{array}$ & Ön test & 22 & 114,8 & 8,4 & 95,0 & 124,0 & & $-1,12$ \\
\hline
\end{tabular}

Eylem ve Harekette Yaratıcı Düşünme Testi

Boyut

\begin{tabular}{llccccccc}
\hline \multirow{2}{*}{ Akıcilık } & Ön test & 22 & 72.3 & 8.6 & 62 & 95 & -1.427 & .154 \\
& Son test & 22 & 75.3 & 9.7 & 63 & 105 & & \\
\multirow{2}{*}{ Özgünlük } & Ön test & 22 & 70.8 & 23.7 & 0 & 91 & & .1 .793 \\
& Son test & 22 & 76.4 & 27.4 & 0 & 115 & & .073 \\
\hline
\end{tabular}

Eylem ve Harekette Yaratıcı Düşünme Testi

Bă̆ımlı Gruplar t Testi

\begin{tabular}{ccccccccc} 
& \multicolumn{1}{c}{$t$} & $t$ & $p$ \\
\hline \multirow{2}{*}{ Hayal gücü } & Ön test & 22 & 83.9 & 14.6 & 60 & 115 & & .1 .452 \\
& Son test & 22 & 90.3 & 17.6 & 53 & 118 & & .161 \\
\hline
\end{tabular}

$p>.01$

Tablo 3 incelendiğinde, yapılan Wilcoxon İşaretli Sıralar Testi sonucuna göre; kontrol grubundaki çocukların Çocuğun Benlik Kavramını Algılaması Ölçme Aracı'na ilişkin ön test puanlarının son test puanlarından istatistiksel olarak farklı olmadığ 1 ( $z=-$ $1.12, p>.01$ ), puan ortalamalarının birbirine yakın olduğu belirlenmiştir. Eylem ve Harekette Yaratıcı Düşünme Testi'ne yapılan Wilcoxon İşaretli Sıralar Testi ve Bağımlı Gruplar t Testi sonucuna göre; kontrol grubundaki çocukların yaratıcılığın akıcılık ( $z=-$ $1.427, p>.01)$, özgünlük ( $z=-1.793, p>.01)$, ve hayal gücü $(t=-1.452, p>.01)$, alt boyutlarının ön test puanlarının son test puanlarından farklılık olmadığı, puan ortalamalarının birbirine yakın olduğu saptanmıştır. 
Tablo 4

Deney Grubundaki Çocuklarin Çocuğun Benlik Kavramını Algılaması Ölçme Aracı ile Eylem ve Harekette Yaratıcı Düşünme Testi'ne İlişkin Ön Test - Son Test ve Kalıcılık Testi Puan Ortalamalarına Ait Anova ve Friedman Testi Sonuçları

\begin{tabular}{|c|c|c|c|c|c|c|c|c|}
\hline & \multirow{2}{*}{ Ölçüm } & \multicolumn{6}{|c|}{ Çocuğun Benlik Kavramını Algılaması Ölçme Aracı } & \multirow{2}{*}{$\begin{array}{l}\text { Anlamlı Fark } \\
\text { (Çoklu Karşılaştırma) }\end{array}$} \\
\hline & & $n$ & $\bar{X}$ & s.s. & $s d$ & $x^{2}$ & $p$ & \\
\hline & Öntest & 24 & 115.375 & 7.197 & \multirow{3}{*}{2} & \multirow{3}{*}{16.710} & \multirow{3}{*}{$.000 *$} & \multirow{3}{*}{$\begin{array}{l}\text { Öntest-Sontest }(\mathrm{p}=.001) \\
\text { Öntest-Kalıcılık }(\mathrm{p}=.001)\end{array}$} \\
\hline & Sontest & 24 & 121.958 & 6.125 & & & & \\
\hline & Kalıcılık & 24 & 121.625 & 5.105 & & & & \\
\hline \multirow{2}{*}{ Boyut } & \multirow{2}{*}{ Test } & \multicolumn{5}{|c|}{ Eylem ve Harekette Yaratıcı Düşünme Testi } & & \multirow{2}{*}{$\begin{array}{l}\text { Anlamlı Fark } \\
\text { (Bonferroni) }\end{array}$} \\
\hline & & $n$ & $\bar{X}$ & s.s. & $s d$ & $F$ & $p$ & \\
\hline \multirow{3}{*}{ Akıcılık } & Öntest & 24 & 70.33 & 5.654 & & & & \multirow{3}{*}{$\begin{array}{l}\text { Öntest-Sontest }(\mathrm{p}=.000) \\
\text { Öntest-Kalıcılık }(\mathrm{p}=.000)\end{array}$} \\
\hline & Sontest & 24 & 92.96 & 13.089 & 2 & 119.747 & $.000 *$ & \\
\hline & Kalıcilık & 24 & 93.29 & 12.561 & & & & \\
\hline \multirow{5}{*}{$\begin{array}{l}\text { Hayal } \\
\text { Gücü }\end{array}$} & Öntest & 24 & 83.54 & 15.096 & & & & \multirow{3}{*}{$\begin{array}{l}\text { Öntest-Sontest }(\mathrm{p}=.000) \\
\text { Öntest-Kalıcılık }(\mathrm{p}=.000)\end{array}$} \\
\hline & Sontest & 24 & 109.50 & 9.960 & 2 & 122.765 & $.000 *$ & \\
\hline & Kalıcilık & 24 & 109.29 & 8.179 & & & & \\
\hline & \multicolumn{7}{|c|}{ Eylem ve Harekette Yaratıcı Düşünme Testi } & Anlamlı Fark \\
\hline & & & & & & $x^{2}$ & $p$ & (Çoklu Karşılaştırma) \\
\hline \multirow{3}{*}{ Özgünlük } & Öntest & 24 & 63.71 & 29.647 & & & & \multirow{3}{*}{$\begin{array}{l}\text { Öntest-Sontest }(\mathrm{p}=.000) \\
\text { Öntest-Kalıc1lık }(\mathrm{p}=.000)\end{array}$} \\
\hline & Sontest & 24 & 103.88 & 16.184 & 2 & 43.300 & $.000 *$ & \\
\hline & Kalıcılık & 24 & 103.58 & 15.030 & & & & \\
\hline
\end{tabular}

Tablo 4 incelendiğinde, yapılan Friedman Testi sonucuna göre; deney grubundaki çocukların Çocuğun Benlik Kavramını Algılaması Ölçme Aracı'na ilişkin ön test, son test ve kalıcılık puan ortalamaları arasındaki farklılığın $\left(x^{2}=16.710, p<.01\right)$ anlamlı olduğu belirlenmiştir. Anlamlı farklılığın hangi ikili gruplar arasında olduğunu belirlemek için yapılan çoklu karşılaştırma testine göre; deney grubundaki çocukların Çocuğun Benlik Kavramını Algılaması Ölçme Aracı'na ilişkin ön test ile son test puan ortalamaları arasındaki farklılığın anlamlı olduğu $(p<.01)$, son test ile kalıcılık testi puan ortalamaları arasındaki farklılığın ise anlamlı olmadığ $1(p>.01)$ belirlenmiştir.

Eylem ve Harekette Yaratıcı Düşünme Testi alt boyutlarına yapılan Anova Testi sonucunda; deney grubundaki çocukların, akıcılık $(F=119.747, \mathrm{p}<.01)$ ve hayal gücü $(F=122.765, p<.01)$ alt boyutları ön test, son test ve kalıc1lık testi puan ortalamaları arasındaki farklılığın anlamlı olduğu belirlenmiştir. Anlamlı farklılığın hangi ikili gruplar arasında olduğunu belirlemek için Bonferroni Testi yapılmıştır. Yapılan Bonferroni Testi sonucuna göre; deney grubundaki çocukların ön test-son test, ön test- 
kalıcılık testi puan ortalamalarının akıcılık ve hayal gücü alt boyutları puan ortalamaları arasındaki farklılığın anlamlı olduğu $(p<.01)$, son test ile kalıcılık testi puan ortalamaları arasındaki farklılığın ise anlamlı olmadığı $(p>.01)$ belirlenmiştir. Yapılan Friedman Testi'ne göre; deney grubundaki çocukların Eylem ve Harekette Yaratıcı Düşünme testi özgünlük $\left(x^{2}=43.300, p<.01\right)$ alt boyutu ön test, son test ve kalıc1lık testi puan ortalamaları arasındaki farklılığın anlamlı olduğu belirlenmiştir.

Şekil 1. Deney Grubundaki Çocuklarin Benlik Kavramini Algılamalarına İlişkin Ön Test Son Test ve Kalıcılık Testi Puan Ortalamaları

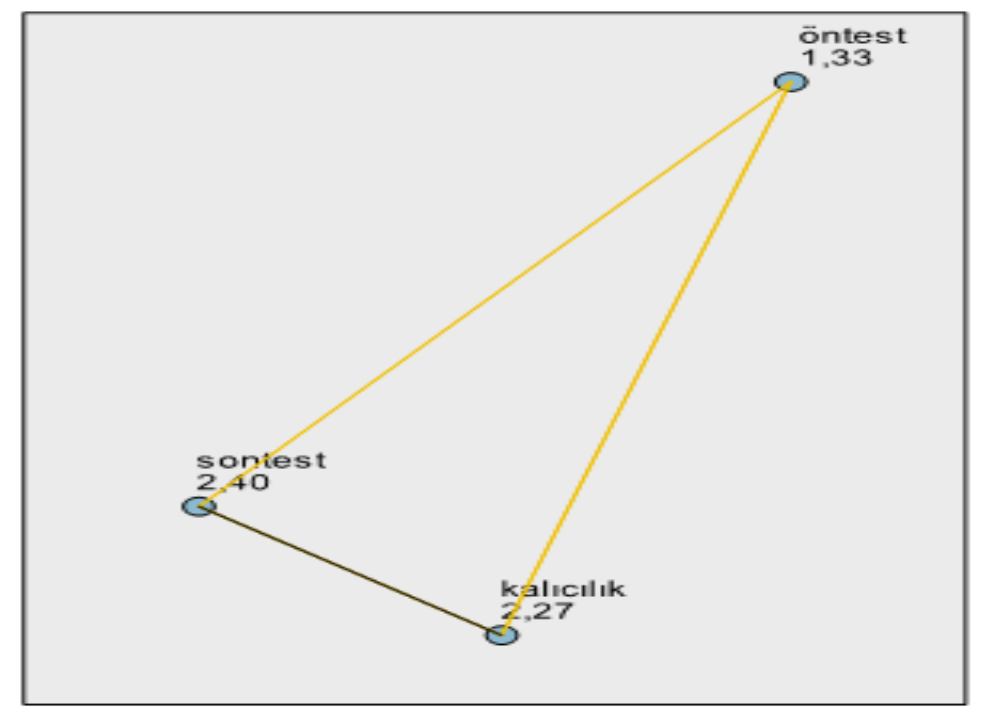

Şekil 2. Deney Grubundaki Çocukların Eylem ve Harekettte Yaratıcı Düşünme Testi'nin Özgünlük Alt Boyutuna Ait Ön Test, Son Test ve Kalıcılık Testi Çoklu Karşılaştırma Sonuçları

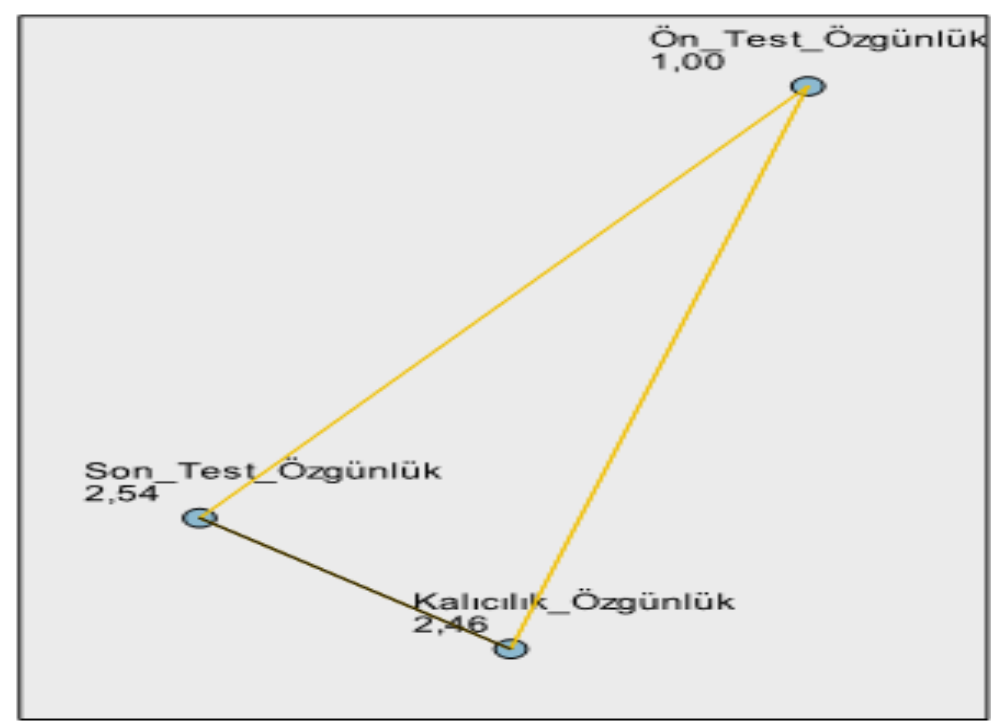


$\mathrm{Bu}$ sonuçlara göre; deney grubundaki çocukların Çocuğun Benlik Kavramını Algılaması Ölçme Aracı ile Eylem ve Harekette Yaratıcı Düşünme Testi’ne ilişkin ön test ile son test puanlarının birbirinden istatistiksel olarak farklı olduğu, son test ile kalıcılık puan ortalamalarının birbirine yakın olduğu belirlenmiştir. $\mathrm{Bu}$ durum, ön testten sonra uygulanan programın çocukların benlik kavramını ve motor yaratıcılıklarını geliştirmede etkili ve kalıcı olduğu sonucunu göstermektedir.

\section{Sonuç ve Tartışma}

Yaratıcı rahatlama eğitim programının, çocukların benlik kavramı ve motor yaratıcılıklarında etkili olup olmadığını incelemek amacıyla yapılan araştırmada, deney ve kontrol grubundaki çocukların "Çocukların Benlik Kavramını Algılama Ölçme Aracı" ile "Eylem ve Harekette Yaratıcı Düşünme Testi”ne ilişkin yapılan ön test puanları arasında anlamlı farklılık olmadığı $(p>.01)$ belirlenmiştir (Tablo 1). Bu bulgulara göre, uygulamaya başlamadan önce deney ve kontrol grubunu oluşturan çocukların benlik kavramlarının ve motor yaratıcılıklarının birbirine yakın (benzer) özelliklere sahip olduğu söylenebilir. Bu durum aynı zamanda deney ve kontrol grubunun homojen olduğunu da göstermektedir.

Deney ve kontrol grubundaki çocukların "Çocukların Benlik Kavramını Algılama Ölçme Aracı" ile Eylem ve Harekette Yaratııı Düşünme Testi”ne ilişkin yapılan son test puanları arasında anlamlı farklılık olduğu $(p<.01)$ belirlenmiştir (Tablo 2). Bu bulgulara gore; deney grubunda yer alan çocukların benlik kavramı ve motor yaratıcılık son test puan ortalamalarının kontrol grubunda yer alan çocukların son test puan ortalamalarından daha yüksek olduğu saptanmıştır. Aynı zamanda deney grubundaki çocukların benlik kavramı ve motor yaratıcılık puanlarının artmasında uygulanan Yaratıcı Rahatlama Eğitim Programının etkili olduğunu göstermektedir.

Kontrol grubundaki çocukların "Çocukların Benlik Kavramını Algılama Ölçme Aracı” ile Eylem ve Harekette Yaratıcı Düşünme Testi”ne ilişkin yapılan ön test ve son test puanları arasında anlamlı farklılık olmadığı $(p>.01)$ ancak puan ortalamalarının arttığı belirlenmiştir (Tablo 3). Yaratıcı Rahatlama Eğitim Programı'na katılmayan çocukların benlik kavramı ve motor yaratıcılık ön test ve son test puanlarında gözlenen olumlu değişmenin, okul öncesi eğitim programında yer alan etkinliklerden kaynaklanabileceği söylenebilir.

Araştırmada deney grubundaki çocukların "Çocukların Benlik Kavramını Algılama Ölçme Aracı" ile "Eylem ve Harekette Yaratıcı Düşünme Testi”ne ilişkin yapılan son test puanları arasında anlamlı farklılık bulunmuştur $(p<.01)$. Deney grubunun sontest ve kalıcılık testi arasında anlamlı farklılık saptanmamıştır (Tablo 4). Yapılan rahatlama çalışmaları ve etkinliklerin çocukların motor yaratıcılık ve benlik kavramlarının olumlu yönde gelişmesine etkisinin olduğu düşünülmektedir. Bu sonuçlara göre, deney grubundaki çocukların benlik kavramı ve motor yaratıcılık puanlarının eğitim öncesinden eğitim sonrasına olumlu yönde değişmesine yönelik elde edilen bulguları destekler niteliktedir. 
Günümüz eğitim kurumlarının aldığı en önemli eleştirilerden birisi, eğitim sürecinde duyguların arka plâna atılmasıdır. Oysa eğitimin önemli amaçlarından birisi de bireye kendi duygularının farkında olabilme ve ifade edebilme becerisini kazandırabilmektir. Bireyin sağlıklı kişilik geliştirebilmesi için duyguların paylaşılması ve dışarıya uygun yollarla aktarılması gerekmektedir (Demirtaş, 2009). Duyguların paylaşılmasında ve dışarıya aktarılmasında Yaratıcı Rahatlama Eğitim Programı'nın önemli bir yer tuttuğu söylenebilir. Bu programda yer alan etkinliklerle çocuğun kendini, ailesini, akranlarını, çevre ve toplumu tanıması, duygularını ifade etmesi farklı yöntemler kullanılarak desteklenmiştir. Özellikle drama ya da canlandırma, doğaçlama gibi çalışmalarla çocuğun kendini hem sözel hem de beden olarak ifade etmelerine firsat verilmiştir. Karadağ ve Çalışkan'a (2008) göre çocuk gözlediği ve yaşadığı olayları değişik rollerle canlandırırken, sıkıntılarını, tedirginliklerini, korkularını, özlemlerini, çeşitli vücut hareketleriyle anlatmaktadır. Bu durum, çocuğa vücudunu koordineli bir şekilde istediği amaca uygun olarak kullanma fursatı vermekte ve becerilerin gelişmesinde çocuğa kendi vücudunun özelliklerini tanıması için yardım etmektedir. Ayrica Yves (2001), vücudumuzdaki gerginlikleri gidermede müzik dinleme, yürüyüşe çıkma, 1lık bir duş alma, dinlenme gibi farklı yolların etkili olduğunu vurgulamaktadır (Akt. Malkoç, 2012).

Çocukları rahatlatmak ve sonucunda yaratıcılıklarını ortaya çıkarmak için yapılan rahatlama çalışmalarında amaç, grup üyelerinin hayal güçlerini ortaya çıkarabilmektir. Bu tür çalışmalar sayesinde hareket etmeye ve hareketli oyunlara katılmaya doğal olarak eğilimli olan çocuk, büyük motor hareketlere dayanan etkinlikler sırasında hem bedensel enerjisini harekete geçirmekte hem de gruptaki diğer çocuklarla sözlü ve sözsüz olarak iletişim kurabilmektedir (Önder, 1999). Öğretmenler çocukları bu tarz hareket keşifleri için cesaretlendirdiğinde, çocuklara kendilerini ifade edebilecekleri sanat, dans ve drama ile ilgili ortamlar sunulduğunda çocuklar kendileri ve çevreleri hakkında çok şey öğrenmektedir (Tegano, Moran \& Sawyers, 1991). Mayesky (1990), yaratıcı potansiyelin en kritik elementinin özgünlük olduğunu, öğretmenlerin özgün düşünmeye yol gösteren açık, özgür bir atmosfer sunmalarının gerektiğini, kendi düşüncelerini özgürce takip etmelerine ve kendi hareketlerini özgürce sergilemelerine izin verdiklerinde bütün çocukların yaratıcı olabileceğini vurgulamıştır.

Özellikle yaratıcılığın bir boyutu olan motor yaratıcılık, okul öncesi dönemde çocukların yaratıcılıklarını geliştirebilmek için önemli bir anahtar deneyimdir. Çünkü çocuklara bedenlerini bireysel olarak ifade etme firsatı vermektedir (Bournelli, Makri \& Mylonas, 2009; Justo, 2008: Torrance, 1981; Wang, 2003;). Hazırlanan Yaratic1 Rahatlama Eğitim Programında rahatlama çalışması ve etkinliklerle çocukların kendilerini bedenleri ile ifade etmeleri için firsatlar sunulmuştur. Bu uygulanmanın sonucunda da çocukların benlik kavramlarında olumlu yönde artış beklenmiştir. Araştırma sonucunda da eğitim programlarına katılan çocukların eğitime katılmayan çocuklara göre benlik kavramı düzeylerinde olumlu bir artış olduğu belirlenmiştir. Yapılan diğer araştırmalar incelendiğinde; uygulanan eğitim programlarının çocuklarda benlik kavramını (Breslin, Murphy, Mckee, Delaneyi \& Demster, 2012; Burnett, 2004; 
Hornery, Seaton, Tracey, Craven \& Yeung, 2014; Kuru Turaşlı \& Zembat 2013; Landry, Schilson \& Parde, 1974; Önder 2006; Şenol Özyiğit 2011; Russell-Bowie, 2013; Uysal \& Balkan, 2015) ve yaratıcılıklarını (Can Yaşar \& Aral, 2010; Cheung, 2010; Erbay, 2009; Erkan, 2005; Garaigordobil \& Berrueco, 2011; Hanson, 1992; Konstandinidou, 2014; Lowery, 1982 ) geliştirdikleri saptanmıştır.

Çocukların benlik kavramını ve motor yaratıcılıklarını desteklemek amacı ile hazırlanmış olan Yaratıcı Rahatlama Eğitim Programı'nda özelikle çocukların kendini farklı yollarla ifade edebilmesine dikkat edilmiş ve bu doğrultuda rahatlama çalışması ve etkinlikler bütünleştirerek hazırlanmıştır. Çağdaş, Albayrak ve Cantekinler (2003) ve Justo (2008) yaptıkları çalışmalarda, rahatlama çalışmalarının arkasından yapılan etkinliklerde bazı materyallerin kullanılmasının hayal gücünün uyarılmasında etkili olduğunu, etkinliğe eğlenceli ve mizahi bir hava getirerek çocukların rahatlamalarını sağladığını vurgulamışlardır. Rahatlama çalışmasından sonra uygulanan etkinliklerde öncelikle çocuğun kendi vücudunu fark edebilmesi amaçlanmıştır. Daha sonra vücudunun farklı uzuvlarını kullanabilmesi ve hareketler yapabilmesi dikkate alınmıştır. Hareket etkinlikleri çocuklara bireyselliklerini, yaratıcılıklarını, maceracı ruhlarını geliştirme ve onları pratik etme firsatı sağlamada etkili olabilir. Bu nedenle iyi düzenlenmiş bir program yalnızca yaratıcılıklarının gelişimine değil aynı zamanda olumlu benlik kavramı gelişime de katkıda bulunabilir. Bournelli vd., (2009) ve Felker ve Treffinger (1971) çocuklarda motor yaratıcılık ve benlik kavramı arasındaki ilişkiyi incelemiş ve motor yaratıcılık ile benlik kavramının ilişkili olduğunu belirtmiştir. Feilth, Renzulli ve Westberg (2002) yaratıcı eğitim programının çocukların kendilerini diğer alanlardaki potansiyellerini fark etme ve daha olumlu bir benlik saygısı geliştirme firsatı sunduğunu belirtmişlerdir. Justo (2008) çalışmasında, yaratıcı rahatlama programına katılan çocukların benlik kavramı ve motor yaratıcılık puanlarında katılmayan çocuklara göre daha yüksek puan aldıklarını saptamıştır.

Yaratıcı Rahatlama Eğitim Programı'nda yer alan drama, oyun, hareket, sanat ve müzik gibi etkinliler yoluyla çocukların kendini ve çevresini tanıma, problem çözme, yaratma, değerlendirme, soru sorma becerilerinin desteklenmesi için tüm çocuklara firsatlar sunulmuştur. $\mathrm{Bu}$ firsatlar sonucunda ise uygulanan eğitim programının çocuğun; bağımsız düşünme yetisinin gelişmesine, yaratıcılık ve estetik gelişiminin sağlanmasına, yeni olumlu davranışlar geliştirmesine, kendine olan güvenini kazanmasına, fiziksel ve sosyal problemleri çözebilme konusunda yaparak yaşayarak deneyim kazanmasına katkı sağladığı söylenebilir. Buradan hareketle yapılan araştırma sonucunda ve diğer araştırma sonuçları incelendiğinde; okul öncesi dönemden itibaren çocuğun benlik kavramını ve motor yaratıcılıklarını geliştirmesini amaçlayan eğitim programlarının uygulanmasını gündeme getirmektedir. Bu araştırmanın sonuçları da araştırma kapsamında geliştirilen ve uygulanan Yaratıcı Rahatlama Eğitim Programı'nın çocukların benlik kavramı ile motor yaratıcılıklarını geliştirmede etkili olduğu sonucunu göstermektedir. 


\section{Öneriler}

Araştırmadan elde edilen sonuçlar doğrultusunda anne babalara ve eğitimcilere aşağıdaki öneriler sunulabilir:

Anne babalar çocukların farklı düşünmelerine olanak sağlayan benlik kavramı ve yaratıcılıklarını desteklemek için harekete dayalı duygularını açığa çıkaracak tiyatro, drama, sanat gibi etkinliklere yönlendirebilir. Özellikle anne ve babalara çocukların gelişimleri hakkında bilgilendirme toplantıları düzenlenebilir. Eğitimciler çocukların olumlu benlik kavramı ve yaratıcılıklarının gelişimi için yapılması gerekenler hakkında aile ile işbirliği yapabilirler. Çocuklara kendilerini hareketleri ile ifade edebilecekleri, rahat eğitim ortamları düzenleyebilirler. Okul öncesi dönemde çocukların hayal güçleri ve merakları oldukça fazladır. Bu nedenle çocuklara hareket etme, hayal gücünü kullanma, keşfetme firsatı vererek, çocukları yeni deneyimler için cesaretlendirebilir ve güdeleyebilirler. Ayrıca yapılan çalışma daha geniş bir örneklem grubuna uygulanarak sonuçları tartışılabilir. 


\section{Kaynakça}

Adana, F. \& Kutlu, Y. (2009). Anne-baba tutumlarının adolesanların kendilik kavramı üzerine etkisi. Atatürk Üniversitesi Hemşirelik Yüksekokulu Dergisi, 12(2), 1823.

Aral, N. (1999). Sanat eğitimi - yaratıcılık etkileşimi. Hacettepe Üniversitesi Ĕ̆itim Fakültesi Dergisi, 15, 11-17.

Aslan, A.E. \& Puccio, G. (2006). Developing and testing a turkish version of torrance es tests of creative thinking: A study of adults. Journal of Creative Behavior, 40(3), 163-178.

Bee, H. \& Boyd, D. (2009). Çocuk gelişim psikolojisi. (Çev: O.Gündüz). İstanbul: Kaknüs Yayınları.

Berk, L. (2013). Çocuk gelişimi. (Çev:A. Dönmez. B.Onur Yayına Haz.). Ankara: İmge Kitabevi.

Bournelli, P. \& Mountakis, C. (2008). The development of motor creativity in elementary school children and its retention. Creativity Research Journal, 20(1), 72-80.

Bournelli, P., Makri, A. \& Mylonas, K. (2009). Motor creativity and self-concept. Creativity Research Journal, 21(1), 104-110.

Breslin, G., Murphy, M., McKee, D., Delaney, B. \& Dempster, M. (2012). The effect of teachers trained in a fundamental movement skills programme onchildren's selfperceptions and motor competence. European Physical Education Review, 18(1), 114-126.

Brown, G.L., Mangelsdorf, S.C., Neff, C., Sullivan, S.J.S. \& Frosch, C.A. (2009). Young children's self-concepts associations with child temperament, mothers' and fathers' parenting, and triadic family interaction. Merrill-Palmer Quarterly, 55(2), 184-216.

Burnett, P.C. (2004). Enhancing Student's self-perceptions : The impact of programs and teacher feedback. Australian Journal of Guidance and Counselling, 14(1), 34-47.

Can, S. (2015). Okul öncesi eğitim kurumlarına devam eden 5-6 yaş çocuklarında akademik benlik saygısı (Muğla İli Örneği). Sosyal ve Beşeri Bilimler Araştırmaları Dergisi, 34, 159-176.

Can Yaşar, M. \& Aral, N. (2010). Yaratıcı düşünme becerilerinde okul öncesi eğitimin etkisi. Kuramsal Eğitimbilim, 3(2), 201-209.

Can Yaşar, M. \& Aral, N. (2011). Altı yaş çocuklarının yaratıcı düşünme becerilerine sosyo-ekonomik düzey ve anne baba öğrenim düzeyinin etkisinin incelenmesi. Kuramsal Eğitimbilim, 4(1), 137-145.

Cheung, R.H.P. (2010). Designing movement activities to develop children's creativity in early childhood education. Early Child Development and Care, 180(3), 377385 . 
Çağdaş, A., Albayrak, H. \& Cantekinler, S. (2003). Okul öncesi eğitimde dramatik etkinlikler. Konya: Eğitim Kitabevi.

Çelebi Öncü, E. (2014). Her yönüyle okul öncesi eğitim 2. E. Çelebi Öncü (Edi.), Yaratıcılığın Keşfi (14-23). Ankara: Hedef Yayıncılık.

Demirtaş, S. (2009). Çocuk yuvasinda kalan korunmaya muhtaç çocukların değer eğitiminde yaratıcı dramanın etkililiği (Yayımlanmamış Doktora Tezi). Hacettepe Üniversitesi, Sosyal Bilimler Enstitüsü, İlköğretim Anabilim Dalı, Ankara.

Demoulin, D.F. (2000). I like me: Enchancing self concept in kindergarten age children through active school / business partnerships. NASP Communique, 27(8), 14-26.

Erbay, F. (2009). Anasınıfina devam eden altı yaş çocuklarına verilen yaratıcı drama eğitiminin çocukların işitsel muhakeme ve işlem becerilerine etkisinin incelenmesi (Yayımlanmamış Doktora Tezi). Selçuk Üniversitesi, Sosyal Bilimler Enstitüsü, Çocuk Gelişimi ve Eğitimi Anabilim Dalı, Konya.

Erkan, H. (2005). Altı yaş grubu çocukların yaratıcılıklarına drama ve rahatlama çalışmalarının etkisi (Yayımlanmamış Yüksek Lisans Tezi). Gazi Üniversitesi, Eğitim Bilimleri Enstitüsü, İlköğretim Anabilim Dalı, Ankara.

Fleith, S.D., Renzulli, S.J., \& Westberg, K.L. (2002). Effects of a creativity training program on divergent thinking abilities and self-concept in monolingual and bilingual classrooms. Creativity Research Journal, 14(3-4), 373-386.

Felker, D.W. \& Treffinger, D.J. (1971). Self concept, divergent thinking abilities, andattitudes about creativity and problem solving. A paper presented at the Annual Meeting, American Educational Research Association, New York. http://files.eric.ed.gov/fulltext/ED047347.pdf Erişim Tarihi: 22.02.2014.

Gallahue, L.D. (2003). Developmental physical education for today's children. Dubuque: C. Brown-Benchmark Publishers.

Garaigordobil, M. \& Berrueco, L. (2011). Effects of a play program on creative thinking of preschool children. The Spanish Journal of Psychology, 14(2), 608-618.

Gürsoy, F. (2001). Çocukta yaratıcılı̆̆ın gelişimi: Ankara Üniversitesi Ev Ekonomisi Yüksek Okulu anaokulu/anasinifi ögretmen el kitabi. İstanbul: Ya-Pa Yayınları.

Hanson, M.A.B. (1992). Developing the motor creativity of elementary school physical education students (Unpublished Doctor Thesis). Georgia Universty, Athens, Georgia.

Hornery, S., Seaton, M., Tracey, D., Craven, R.G., \&. Yeung, A.S. (2014). Enhancing reading skills and reading self-concept of children with reading difficulties: adopting a dual approach intervention. Australian Journal of Educational \& Developmental Psychology, 14, 131-143.

İnan, H.Z. (2013). Okul öncesi dönem çocuklarında sosyal ve duygusal gelişim (Çev:B. Akman). In J. Trawick Swith (Ed.), Erken çocukluk döneminde gelişim (196222). Ankara: Nobel Yayınc1lık. 
Justo, C.F. (2008). Creative relaxation, motor creativity, self-concept in a sample of children from early childhood education. Electronic Journal of Research in Educational Psyvhology, 6(1), 29-50.

Karaca, N.H. (2015). Yaratıcı rahatlama çalışmalarının anaokuluna devam eden çocukların benlik kavramı ve motor yaratıcılı̆̆ına etkisinin incelenmesi (Yayımlanmamış Doktora Tezi). Ankara Üniversitesi Fen Bilimleri Enstitüsü Çocuk Gelişimi ve Eğitimi Anabilim Dalı, Ankara.

Karadağ, E. \& Çalışkan, N. (2008). Kuramdan uygulamaya ilköğretimde drama. Ankara: Anı Yayıncılık.

Konstantinidou, E. (2014). Creativity in physical education: emphasis and development.

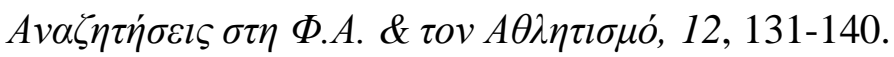

Köksal-Akyol, A. \& Sali, G. (2013). Yatılı ve gündüzlü okuyan çocukların benlik kavramlarının ve sosyal destek algılarının incelenmesi. Kastamonu Ĕ̈itim Dergisi, 21(4), 1377-1398.

Kuru Turaşl1, N. \& Zembat, R. (2013). 6 yaş grubu çocuklarda "benlik algısını desteklemeye yönelik sosyal-duygusal hazırlık programı"nın etkililiğinin incelenmesi. Nevşehir Üniversitesi Sosyal Bilimler Enstitüsü Dergisi, 2, 1-16.

Landry, R.G., Schilson, E., \& Parde, E.M. (1974). Self concept enhancement in a preschool program. The Journal of Experimental Education, 42(4), 39-43.

Lowery, J. (1982). Developing creativity in gifted children. Gifted Child Quarterly, 26(3), 133-139.

Makero, S.C. (2012). The Preconditoning factors to a child's creative mind in a family set-up. Journal of Emerging Trends in Educational Research and Policy Studies (JETERAPS), 3(6), 964-973.

Malkoç, T. (2012). Gevşeme tekniklerinin ses eğitimine katkısı üzerine bir inceleme. Journal of Research in Education and Teaching, 1(2), 101-109.

Marx, R.W. \& Winne, P.H. (1975). Self-concept and achievement: Implications for. Educational Programs Equity \& Excellence in Education, 13(1), 30-31. DOI:10.1080/0020486730130109

Mayesky, M. (1990). Creative activities for young children. New York: Thomson Delmar Learning.

Oakley, L. (2004). Cognitive development. London and Newyork: Psychology Press.

Ömeroğlu, E. \& Turla, A. (2001). Okul öncesi dönemde yaratıcılık eğitimi ve desteklenmesi. Milli Ĕgitim Dergisi, Temmuz, A ğustos, Eylül, 151.

Önder, A. (1999). Yaşayarak öğrenmek için eğitici drama. İstanbul: Epsilon Yayıncılık.

Önder, A. (2006). Eğitici drama uygulamalarının altı yaş çocuklarının kendilik algısı üzerindeki etkisi. Kazım Karabekir Ĕ̆itim Fakültesi Dergisi, 13, 29-34

Özkara, Y. (2014). İlköğretim birinci sınıf öğrencilerinin benlik algısı düzeyinin incelenmesi. International Journal of Human Sciences, 11(1), 642-654. 
Passer, M.W. \& Smith, R. (2003). The science of mind and behaviour. New York: McGraw-Hill Companies, Inc.

Pesu, L., Viljaranta, J., \& Aunola, K. (2016). The role of parents' and teachers' beliefs in children's self-concept development. Journal of Applied Developmental Psychology, 44, 63-71. doi:10.1016/j.appdev.2016.03.001

Russell-Bowie, D. (2013). Wombat stew: Enhancing self concept through an integrated art project. International Journal of Education \& the Arts, 14(17), 1-11.

Schempp, P.G. (1981). Influence of decision-making on attitudes, creativity, motor skills, and self-concept in elementary children (Unpublished Doctor thesis). Boston University, Boston.

Spilt, J.L., Van Lier, P.A., Leflot, G., Onghena, P., \& Colpin, H. (2014). Children's social self-concept and internalizing problems: The influence of peers and teachers. Child Development, 85(3), 1248-56.

Şenol (Özyiğit), E.N. (2011). İlköğretim matematik dersinde yaratıcı drama uygulamalarının ögrencilerin problem çözme stratejileri, başarı, benlik kavramı ve etkileşim örüntüleri üzerindeki etkisi (Yayımlanmamaış Doktora Tezi). Dokuz Eylül Üniversitesi Eğitim Bilimleri Enstitüsü Eğitim Bilimleri Anabilim Dalı Eğitim Programları ve Öğretim Programı, İzmir.

Tegano, D.W., Moran, J.D. \& Sawyers, J.K. (1991). Creativity in early childhood classrooms. Washington, D.C.: National Education Association.

Tortamış Özkaya, B. (2013). Bebekler ve çocuklar doğum öncesinden orta çocukluğa (Çev:N. Işıkoğlu Erdoğan). In L.E. Berk (Ed.), Erken çocuklukta duygusal ve sosyal gelişim (246-285). Ankara: Nobel Yayıncılık.

Torrance, E.P. (1981). Thinking creatively in action and movement. Bensenville, IL: Scolastic Testing Service.

Uysal, A. \& Balkan, K.İ. (2015). Sosyal beceri eğitimi alan ve almayan okul öncesi çocukların, sosyal beceri ve benlik kavramı düzeyleri açısından karşılaştırılması. Psikoloji Çalışmaları Dergisi, 35(1), 27-56.

Villa, A., \& Auzmendi, E. (1992). Medicion del autoconcepto en la edad infantil 5-6 anos (Measuring self-concept in early childhood 5-6 years). Bilbao: Mensajero.

Wang, J.H.T. (2003). The effects of creative movement progrem on motor creativity and gross motor skills of preschool children (Unpublished Doctor thesis). The Universty of South Dakota: South Dokato.

Yıldız Çiçekler, C. \& Alakoç Pirpir, D. (2015). 48-72 aylar arasında çocuğu bulunan annelerin çocuk yetiştirme davranışları ile çocuklarının benlik kavramlarının incelenmesi. Hacettepe Universty Faculty of Health Sciences Journal, 1(2), 491500. 